\title{
The Relationship Threshold Inflation with Fisher Effects in Indonesia: An Investigation Using Bounds Test
}

\section{Antoni}

Bung Hatta University, Padang, Indonesia

\section{Abstract}

This study aims to examine the validity of the Fisher hypothesis and the threshold of inflation in Indonesia in the period 2000-2018. The difference with previous research is not to examine the long-term relationship of the variables studied, because previous research shows that the results are very sensitive to samples in selected countries, study periods and methodologies. Therefore, this study, unlike previous research, because the inflation threshold variable also determines in the Fisher hypothesis

Corresponding Author:

Antoni

toni819975@gmail.com

Received: 18 January 2019

Accepted: 24 March 2019

Published: 31 March 2019

Publishing services provided by

Knowledge E

(c) Antoni. This article is

distributed under the terms of

the Creative Commons

Attribution License, which

permits unrestricted use and

redistribution provided that the

original author and source are

credited.

Selection and Peer-review under the responsibility of the First ELEHIC Conference Committee.

\section{G OPEN ACCESS} analysis. Besides that the difference with previous research in terms of methodology using Autoregressive Distributed Lag Method (ARDL), which is not bound whether the variable is stationary at $I(0)$ or $I(1)$. The results of the study found that the Fisher Hypothesis has a coefficient value of one in the long run. This finding means that inflation and the threshold of inflation do not affect the real sector and will be absorbed by nominal interest rates, then money is 'neutral'. Therefore the implications of this study are very important for determining this Fisher effect for the implications of monetary policy.

Keywords: Interest rate, inflation, fisher hypothesis. Monetary Policy, ARDL.

\section{JEL: E31, 040.}

\section{Introduction}

The relationship of inflation to interest rates begins with Fisher's writing in 1930. There are two reasons that explain the relationship as stated by Mundell and Tobin [1]. This relationship applies when inflation will increase, so it will shift the demand curve. As soon as real money stocks or demand for money will decline, the demand curve for money will increase. This relationship also applies if the increase in borrowed money offers will have an impact on price increases and consequently the real interest rate will decrease. The second is Fisher's influence [2]. This reasoning applies that economic 
actors will be compensated due to an increment in the inflation rate, which is in the shape of a real interest rate premium $[3,4]$.

Fisher's opinion, the inflation rate will cause the nominal interest rate to change at the same level. If this applies, the effect of the real sector is zero. However, the real interest rate is only influenced by the real sector in the long run such as government spending and but does not affect financial sector policy. This means that if the fisher hypothesis is valid then money is considered neutral. Changes in the quantity of money will only cause the price level to change at the same level. Meanwhile, relative prices, real interest rates, real income and output will not change. Given the importance of the implications of this research, many previous studies conducted empirical studies of state-dependent testing of the validity of Fisher's hypothesis.

Based on the above explanation, the main objective of the research is to empirically examine the relationship between nominal interest rates and inflation based on the latest data. In addition, this research is important to view some previous studies have not agreed to get one result of research on the form of long-term relationships of these variables. Because some previous studies only used a number of selected country samples (time and year) and the situation of some countries that experienced fluctuating inflation. Therefore, using the latest data is important to test the relationship of these variables including the prevailing inflation threshold.

In fact, the results of each study may have different implications for the financial policies of a country. It is interesting to find some researchers if money is neutral and if Fisher's neutral hypothesis is met, the nominal interest rate can be used as a prediction that is not biased towards future inflation expectations [5]. Therefore research on the relationship of these three variables is important for investors and governments in planning investment activities. But the real interest rate is determining economic growth, savings and investment. This is because every change in tax from financial assets in real terms will have an impact on economic growth [6].

Figure 1, shows the trend in interest rates and inflation rates in Indonesia from 2000 to 2018. In the figure, the nominal interest rate exceeds the inflation rate. This means that the real interest rate is positive throughout the study period. The nominal interest rate and inflation rate have a low trend from year to year.

The nominal interest rate and inflation rate have a low trend from year to year. In table 1 , it produces descriptive statistics, where the inflation rate defined is a change from the Consumer Price Index of only about $2.78 \%$ and the highest reached 2005 with $17.11 \%$. On average, the min value of the inflation rate is $6.92 \%$ and the nominal interest rate is $8.56 \%$. The standard deviation value is higher for the inflation rate with a value of 3.88 


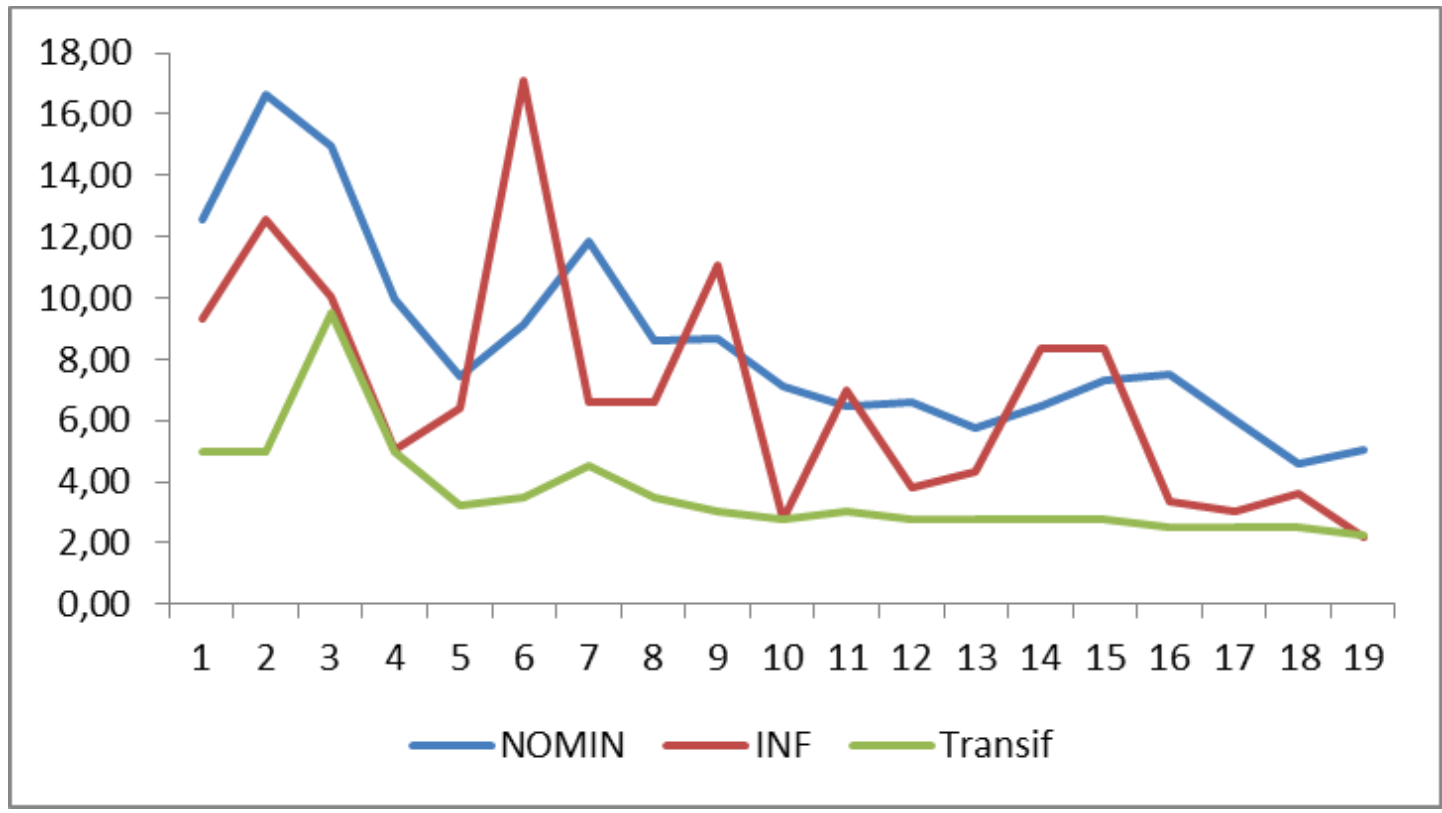

Figure 1: The relationship, nominal interest rate, inflation and Threshold inflasi. Source: Bank Indonesia, Indonesian Financial Statistics, 2000-2018 [7].

compared to the nominal interest rate of $3.29 \%$, while the inflation threshold is only 1.69 which is lower than the inflation rate and nominal interest rate. This means that inflation and nominal interest rates fluctuate more than the inflation threshold.

TABLE 1: Descriptive Analysis of Nominal Interest Rates, Inflation Rates and Treshold Inflation.

Average
Stadar deviation
Variation coefficient
Minimum
Maxsimum

\begin{tabular}{|c|}
$\begin{array}{c}\text { Nominal interest } \\
\text { rate }\end{array}$ \\
\hline 8.5605 \\
3.2939 \\
\hline 0.3848 \\
4.5600 \\
\hline 16.6200
\end{tabular}

\begin{tabular}{|l|}
\hline Inflation \\
\hline 6.9221 \\
\hline 3.8816 \\
\hline 0.5608 \\
\hline 22000 \\
\hline 17.1100 \\
\hline
\end{tabular}

\begin{tabular}{l}
$\begin{array}{l}\text { Treshold } \\
\text { Inflation }\end{array}$ \\
\hline 3.6184 \\
1.6902 \\
\hline 0.4671 \\
\hline 2.2500 \\
\hline 9.5000 \\
\hline
\end{tabular}

\section{Literature Review}

The previous researcher also examined the value of the relationship between inflation and the nominal interest rate depending on the use of the sample, the state of the country's economy and the methodology used. But almost most researchers use the same method as the Johansen-Juselius cointegration technique, but the results obtained are still different [8]. For example research by Moazzami in the US supports the Fisher hypothesis [9]. But other studies in the same country also get nominal interest 
rates that are not systematically related to inflation premiums [10]. he results of research from several other countries also showed no cointegration between nominal interest rates and inflation failed to be rejected for US, Belgium, Canada and UK countries. [11].

While other researchers also found that tighter inflation targeting and more active monetary policy would reduce the adjustment of nominal interest rates to expected changes in inflation [12]. Similar research also examined the relationship between the interest rates of Bank Indonesia certificates (SBI), inflation and the composite stock price index (IHSG) in Indonesia in January 2006-December 2010. Using the Vector Auto Regression (VAR) test method, there was a causal relationship and significant between variable inflation and interest rates on Bank Indonesia certificates (SBI), but there is no causal relationship between inflation and index of joint stock prices (ISHG) [13].

Some researchers also make a difference in examining the relationship between nominal interest rates for different financial assets depending on time and inflation. The results of the study show that the higher the level of maturity of assets, the stronger the relationship that manifests the relationship between the two variables. That is, for assets with long maturity, the Fisher hypothesis is only valid or real. However, in the same study the relationship or Fisher's short-term influence was not significant. This is because the short-term interest rate has little effect on anticipating inflation [3]. Other studies before this also gave different decisions, where Fisher's hypothesis was under a fixed exchange rate regime, but the reverse did not apply under the flexible exchange rate regime [11].

The same study was conducted in Indonesia, examining the relationship of these two variables in the long run in the 1990s using Johansen-Juselius cointegration techniques. Besides Indonesia, this study also includes samples from 4 other ASEAN countries. Their results support the form of tax adjustments for Singapore, Indonesia and Thailand. This means that the real exchange rate stability has empirical support in countries with low inflation rates. However, the Fisher hypothesis is rejected for countries that have high inflation rates, such as the Philippines and Indonesia [5].

The study examined the causality relationship between the BI Rate and inflation in the period 2005-2011. By using the Toda-Yamamoto causality test the results of the study found that the second data is variable stationarity first level difference. The results of the study also found that there was a causality relationship within two months of the two variables [14]. Whereas the research that conducted the cointegration test and the causality of interest rates and inflation in Pacific countries revealed that there was no cointegration relationship between the two variables. Then the causality test between the two variables is not found in the causality test [15]. 
In another study carried out through the Yamamoto Toda and ARDL causality test approach of the same variable in Iran. The results obtained that there is a causality relationship in the direction of the interest rate towards the inflation rate for both approaches [16]. Then the last is a study that examines the causality of monetary policy with inflation in Indonesia in the 2000-2007 period. The results show that changes in the BI Rate will affect inflation in a two-month period [17]. Research that examines cointegration and causality relationships between variables that are examined in Turkey in the long run. That is, the nominal interest rate and inflation move together in the long run. The results of Granger causality indicate a unidirectional relationship of these two variables [18].

In contrast to previous research, which results in a study of the absence of support for cointegration between inflation and nominal interest rates $[19,20]$. Other studies also found no Fisher Effect in all three countries, namely Japan, Sweden and Italy. It was found that nominal interest rates cannot respond to point-to-point inflation rates [21]. By conducting the same research, it was also found that testing of Fisher effect was invalid and uninformative as the actual state of the hypothesis for the Fisher Effect for the long term [22]. There have been several researchers conducting empirical studies of Fisher's effects in the United States and Canada in 1953 to 1999 in the post-war period. Using the ARDL-bound test approach, it results in rejecting the null hypothesis from the influence between nominal interest rates and inflation in the long run [23].

Research conducted in Malaysia, examining interest rates and inflation: further evidence using the ARDL method using the Bound test approach. The results of the study found that the form of Fisher's influence in the long run and its value is one. This means that each inflation shock will only increase the nominal interest rate at the same level. Therefore, real factors do not change which means that financial policy is 'neutral' [24]. Some researchers also found that there was a more stable relationship between variable interest rates and inflation compared to monetary aggregates [25, 26].

Looking at several studies giving different results regarding the Fisher hypothesis, this hypothesis is very much needed to be tested further. In other words, the research on Fisher's influence and perceived threshold of inflation needs to view previous researchers both inside and outside the state, failing to get a single agreement on the form of the long-term relationship between nominal interest rates and inflation.

However, in this study, it is necessary to examine how much the threshold of inflation can be tolerated and does not have a negative impact on the economy depending on the characteristics of the economy. Some studies that review the threshold are based on the relationship between inflation and non-linear economic growth [27]. However, some reviewers also concluded the results of the study that the threshold of inflation was at 
the top level, meaning that the relationship between inflation and economic growth was negative and significant. This means that inflation significantly slows growth estimated at 1-3 percent for industrialized countries and 11-12 percent for developing countries [28]. While the results of other reviewers' research also get the inflation threshold value for Asian countries is 5.45\% [29]. While research using the threshold Autoregressive (TAR) method, results in a long-term relationship between the two verbs. In addition, the findings are asymmetrical changes in the disruption of inflation [30].

There are several previous researchers who reviewed the Fisher hypothesis using the cointegration test method. The corrective rectification vector test (VECM) results in a research in the form of a long-term relationship, while for the short term by entering the term corrective correction (ECT), there is a direction of the causal relationship between the independent variable and the dependent variable is long-term or short-term [3, 5, 3135]. But there is an opinion that inflation in Indonesia is a monetary phenomenon that has a broad influence on the macroeconomic conditions of a country in the short and long term. For this reason, controlling inflation needs to be controlled so that it remains low and stable [36].

Therefore, there is one major disadvantage of this cointegration test method using two methods Johansen-Juselius and Granger, which requires the terms of both inflation variables, inflation threshold and the stationary nominal interest rate at the same level of difference, $\mathrm{I}(1)$. This may be difficult to achieve for certain data at different times $[8,37]$. Because this study uses the ARDL (Autoregressive Distributed Lag) method that can overcome the weaknesses of the cointegration test [38]. ARDL goodness is the relationship between variables can be tested without the need to look at the degreeation between variables whether stationary or not at the level I(0) or the first difference I(1) in the long run [39]. In addition, this ARDL method also allows the tested model to take the optimum lag number and is sufficient to describe the data from the framework of the general model to specific [40].

\section{Method of Research}

\subsection{Data}

In this study using quarterly data from year 2000 to 2018 . The inflation rate is achieved by using the Consumer Price Index (CPI) growth rate. Threshold of inflation in research conducted [28]. In this study the existence of the inflation threshold is used by adding inflation variables that have been squared into the model as done by Khan and Senhadji 
(2001). While the nominal interest rate is proxied by the interest rate (3 Bill). Data sources were obtained from SEKI Bank Indonesia and Asean Development Bank (ADB) data.

\subsection{Model specifications}

The dynamic model of rectification corrections (ECM) can be obtained from ARDL through simple linear transformations [41]. To explain the ARDL model approach, the model specifications that show the relationship between Fisher hypothesis and inflation thresholds are formed as below:

$$
\text { Nomint }_{t}=\alpha+\beta \text { Inf }_{t}^{e}+\delta \text { Tresinf }_{t}^{* e}+\varepsilon_{t}
$$

where nomin ${ }_{t}, \operatorname{Inf}_{t}^{e}$ and Tresinf $_{t}^{* e}$ are nominal interest rates, inflation rates, and inflation thresholds. is the vector terma stochastic error when $\alpha$ and $\beta$ are parameters. Furthermore, to estimate the effect of inflation, the inflation threshold of nominal interest rates in the long run is used by the ARDL model as done by Pesaran et al. (2001). in the long run. However, first the testationation test is carried out to ensure the regeneration of each variable is not in stage I(2). It should be explained that the cointegration test based on the ARDL approach can be applied without considering whether all variables are stationary at I(0) or I(1). To test the data validation, the Augmented Dickey-Fuller and Phillips-Perron tests [42, 43], were carried out as follows:

$$
\Delta \mathrm{X}_{t}=\beta_{0}+\beta_{1} \mathrm{X}_{t-1}+\sum_{i=1}^{k} \beta_{i} \Delta X_{t-i}+\varepsilon_{t}
$$

Based on equation (1) above, the version of the ARDL model for rectification can be written as follows:

$$
\begin{aligned}
\Delta \text { Nomint }_{t}= & \alpha_{0}+\sum_{i=1}^{p} \beta_{1} \Delta \text { Nomint }_{t-1}+\sum_{i=0}^{q} \beta_{2} \Delta \operatorname{snf} f_{t-i}^{e}+\sum_{i=1}^{r} \beta_{3} \Delta \operatorname{Tresin} f_{t-i}^{* e} \\
& +\lambda_{1} \text { iNomint }_{t-1}+\lambda_{2} \operatorname{Inf}_{t-1}+\lambda_{3} \operatorname{Tresin} f_{t-1}^{* e}+\omega_{1 t}
\end{aligned}
$$

In equation 3 , where $\Delta$ is the operator of the first difference, the first for efficient $\beta_{1}$ and $\beta_{2}$ describes a short-term dynamic model whereas for the second, $\lambda$ indicates a long-term relationship between variables while the hypothesis test used the F-statistical test, i.e. The null hypothesis is $\lambda_{1}=\lambda_{2}=\lambda_{3}=0$ and means that there is no long-term relationship. Equation (3) will be estimated using the ARDL Bound test approach.

Hypothesis test of ARDL model through bound test with null hypothesis, namely there is no cointegration. $F$ value The calculated statistic will be compared with the critical 
value in the table $[38,39]$. If the statistical value is calculated to exceed the upper critical value, then the null hypothesis that is not the form of a long-term relationship is rejected without considering the degree of regeneration of each variable. This means a form of long-term relationship. Similarly, if the statistical value is less than the lower critical value, then the null hypothesis is also rejected which means a form of long-term relationship. Conversely, if the F statistic value is between the lower bound and upper bound table, the decision cannot be concluded (inconclusive).

To get the best ARDL model and be sufficient in terms of the number of lags and variables used, a diagnostic test is needed. For example the lagrange multiplier serial correlation test uses the Breusch-Godfrey test, ARCH test, Jarque Bera normality test and stability test using the CUSUM test.

\section{Empirical Results}

\subsection{Test results for unit root}

The inflation time sequence data and nominal interest rate were tested for validation using the Augmented Dickey Fuller (ADF) method. The decision on the degreeation test can be presented in Table 2. The amount of lag is determined by Akaike information criteria [44]. Based on the table, the inflation variable (Inf) is obtained, the inflation threshold (Tresinf) has been stationary at the Level I(0) stage while the nominal interest rate variable (Nomin) is not stationary at $I(0)$ but stationary in the first difference $I(1)$. Indeed, the next estimate will be to use the ARDL approach to examine the long-term relationship between nominal interest rates and inflation even though the rate of regeneration is not the same. The appropriate ARDL method is applied to view the conditions, namely the dependent variable (Nomin) must be stationary at the first difference, I(1) [38].

\subsection{Ardl bound test}

In this study using the ARDL test method the Bound Test approach is presented in Table 3. The results of the study using the ARDL Bound test approach as shown in Table 3 find are significant relationship between the free to nominal interest rates in the long run. Whereas with the short-term cause test through the Wald test shows the cause of Granger. However the Fisher hypothesis not only has a long-term relationship between the variavel studied, instead the value of the Fisher elasticity coefficient hypothesis is also one. This means that Fisher's influence is fulfilled if the nominal interest rate acts 
TABLE 2: Results of the unit root test.

\begin{tabular}{|c|c|c|c|c|}
\hline \multicolumn{5}{|c|}{ Panel A: Level } \\
\hline \multirow[t]{2}{*}{ Variabel } & \multicolumn{2}{|c|}{ ADF } & \multicolumn{2}{|c|}{ PP } \\
\hline & Without Trend & With Trend & Without Trend & With Trend \\
\hline Nomint & -2.1543 & $-3.7007^{* *}$ & -1.6225 & -2.7530 \\
\hline Inf & $-3.1236^{* *}$ & -3.1148 & $-3.1124^{* *}$ & -3.0736 \\
\hline Tresinf & $-2.8856^{* * *}$ & $-4.9119^{*}$ & $-2.8755^{* * *}$ & $-3.1762^{* * *}$ \\
\hline \multicolumn{5}{|c|}{ Panel B. First diference } \\
\hline \multirow[t]{2}{*}{ Variable } & \multicolumn{2}{|c|}{ ADF } & \multicolumn{2}{|c|}{ PP } \\
\hline & Without Trend & With Trend & Without Trend & With Trend \\
\hline Nomint & $-4.1940^{*}$ & $-4.1633^{*}$ & $-4.2212^{*}$ & $-4.1894^{*}$ \\
\hline $\operatorname{lnf}$ & $-10.4775^{*}$ & -10.4883 & $-10.4959^{*}$ & $-10.5840^{*}$ \\
\hline Tresinf & $-6.3756^{*}$ & $-6.3471^{*}$ & $-9.5457^{*}$ & -9.8378 \\
\hline \multicolumn{5}{|c|}{ Note: ADF and Phillip Perron test without trends and with trends } \\
\hline
\end{tabular}

in response to changes in inflation and inflation thresholds. The reviewer of the Fisher hypothesis in Canada also gets results, the value of the elasticity coefficient is 1.52 to 1.95 [45]. But the same research conducted in the US obtained the coefficient obtained was 1.4 [46].

In Table 4, Describe the results of the boundary cointegration test, using the hypothesis $\beta_{1}=\beta_{2}=\beta_{3}=0$, resulting in the null hypothesis being rejected at a significant level of 1\%. This is because the calculated F-statistic value obtained is 8.5267 greater than the upper limit value of 6.36. the results obtained from the variable nominal interest rate, inflation and threshold inflation have a long-term relationship.

To determine the long-term elasticity coefficients and short-term causation tests obtained through the F test using the Wald test are stated in Table 5. The results of the study obtained by an increase in inflation and inflation threshold, will increase the nominal interest rates of 0.4561 and 0.8335 respectively. Based on the results of previous studies, the results of this study also support the Fisher hypothesis. From the results of the study found a positive and significant relationship of the variables studied and approached one in the long term and consistent with the researchers before this.

The results of the causality test of the variables studied in the short term using the Wald test result in a causality relationship. This means that inflation and threshold inflation variables occur in granger relationships at a significant level of $5 \%$. 
TABLE 3: Estimated Fisher Equations using the ARDL Bound test.

\begin{tabular}{|c|c|c|c|}
\hline \multicolumn{4}{|c|}{ I. Model Estimates } \\
\hline Variabel & Coeficient & t-Statistic & Prob. \\
\hline $\operatorname{Nomin}_{t-1}$ & $-2.4032^{*}$ & -3.9297 & 0.0057 \\
\hline $\mathrm{INF}_{t-1}$ & $1.2891^{*}$ & 3.8366 & 0.0064 \\
\hline Tresinf $_{t-1}$ & $1.6933^{* *}$ & 2.4372 & 0.0449 \\
\hline$\beta_{0}$ & $3.6466^{*}$ & 4.0341 & 0.0050 \\
\hline$\Delta$ Nomin $_{t-1}$ & 0.4007 & 1.2307 & 0.2582 \\
\hline$\Delta \mathrm{INF}_{t-1}$ & $-0.7841^{* *}$ & -3.0857 & 0.0177 \\
\hline$\Delta \mathrm{INF}_{t-2}$ & $-0.3047^{* *}$ & -2.7009 & 0.0306 \\
\hline$\Delta$ Tresinf $_{t-1}$ & -0.4650 & -1.7754 & 0.0175 \\
\hline$\Delta$ Tresinf $_{t-2}$ & $-0.4082^{* *}$ & -3.0926 & 0.0175 \\
\hline \multicolumn{4}{|c|}{ II. Criteria Model - Goodness of fit } \\
\hline \multicolumn{4}{|c|}{$R^{2}=0.9396$ Adjusted $R^{2}=0.8706$ F-Statistic $=13.61823[0.0012]^{*}$} \\
\hline \multicolumn{4}{|c|}{ III. Diagnostic test } \\
\hline \multicolumn{4}{|c|}{$\begin{array}{l}\mathrm{LM}_{(S C)}(2)=0.3658[0.7107] \mathrm{ARCH}^{-t e s t}(1)=0.0448[0.8355] \mathrm{JB}^{-t e s t}{ }_{(N)}=6.4524 \\
{[0.0397] \mathrm{RESET}=0.4963[0.4834]_{\text {Cusum }}{ }_{(S Q)}=\text { Ujud Perubahan Struktur }} \\
\text { (Structural Break). }\end{array}$} \\
\hline \multicolumn{4}{|c|}{$\begin{array}{l}\text { Nota: } \mathrm{LM}_{(S C)} \text { adalah Lagrange multiplier test serial correlation (Breusch- } \\
\text { Godfrey test); ARCH-test = Heteroscedasticity test; } \mathrm{LM}_{(N)}=\text { Serial Correlation; } \\
\text { JB = Jargue -Bera Normality test; RESET = Ramsey -test dan CUSUM }{ }_{(S Q)} \\
\text { Structure break test. }\end{array}$} \\
\hline
\end{tabular}

TABLE 4: Bounds test for cointegration analysis.

Critical value
$1 \%$
$5 \%$
$10 \%$

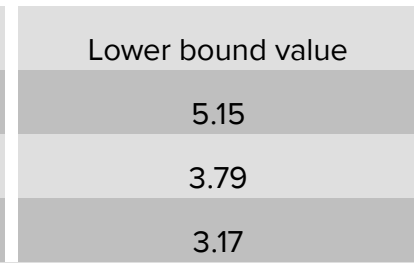

Upper bound value
6.36
4.85
4.14


intercept and no trend [37].

The results of the next study tested the Fisher hypothesis and inflation threshold with a diagnostic test to determine the accuracy and adequacy of the model. Based on the diagnostic test in Table 3, the LM test shows that the residual is white noise with min zero and the variant is constant. The $\mathrm{ARCH}$ test also gets the null hypothesis, which is not the form of the ARCH effect, which was successfully rejected and this does not mean the form of $\mathrm{ARCH}$ influence in the model. Normal testing using the Jarque Bera test shows the data used in the model is normal. Furthermore, the results of the Ramsey Reset test found that there were no problems in the specification of the model if the 
TABLE 5: The long run Elastisitas and Short run Causality of Nominal Interset rate in Indonesia.

\begin{tabular}{|c|c|}
\hline \multicolumn{2}{|c|}{ I. Long run Estimation Coefficient } \\
\hline Variable & Coefficient \\
\hline INF & $0.4561^{* a}$ \\
\hline Tresinf & $0.8335^{* a}$ \\
\hline \multicolumn{2}{|c|}{ II. Short-run Causality test (Wald test F-Statistic) } \\
\hline$\triangle \mathrm{INF}$ & $\Delta$ Tresinf \\
\hline $4.7772^{* *}$ & $4.8846^{* *}$ \\
\hline$[0.0492$ & {$[0.0470]$} \\
\hline \multicolumn{2}{|c|}{ Note: INF = Inflation; Tresinf = Treshold inflation } \\
\hline
\end{tabular}

null hypothesis, which is not a problem, the model specification failed to be rejected. However, there is a problem of structural break in the economic crisis, if the CUSUM statistical line is different and exceeds the interval of the confidence of $5 \%$ confidence as shown in Figure 2 below. Overall, the results of this diagnostic test decision are in accordance with the time sequence data used.

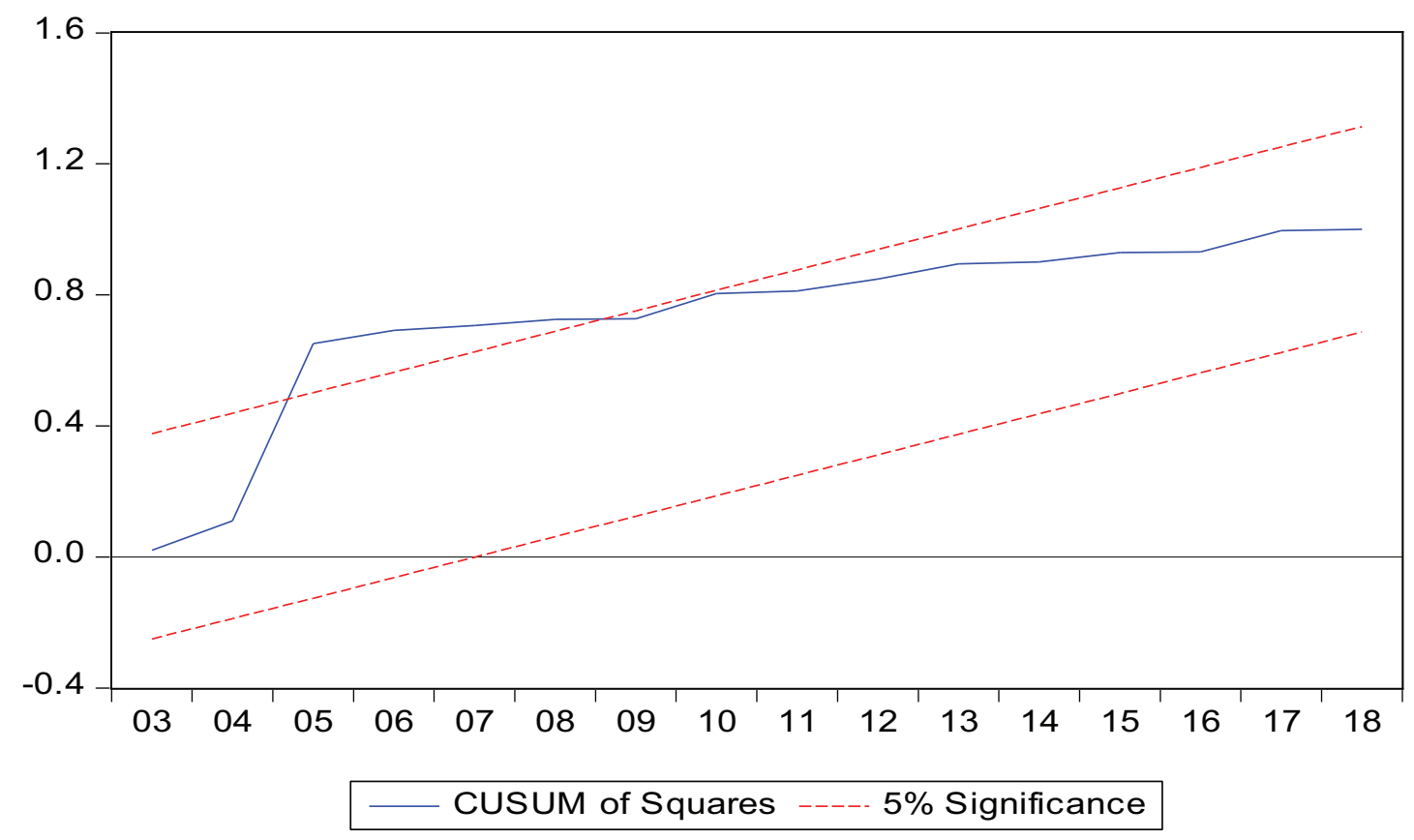

Figure 2: Stability test using the CUSUM test. 


\section{Conclusion and Research Implication}

This study aims to examine the relationship between inflation threshold and Fisher's effect [2]. In this study, it is different from the previous research, but in this study the Fisher hypothesis hypothesis examiner with an inflation threshold only uses the Autoregressive Distributed Lag (ARDL) method with a Bound test approach, which is a method that is more influential and does not require testing and estimation of each variable. The research covers the time of research in 2000-2018. The results of the study show that indeed the effect of Fisher has a value equal to one in the long run, while the effect of threshold inflation on the interest rate has a significant effect. This means that the Fisher hypothesis is fulfilled where each inflation and threshold shock will increase the nominal interest rate at the same level in the long run. Using the Wald test results in a granger relationship at a significant level of $1 \%$ in the short term.

The empirical results also prove that the inflation threshold has a negative effect on growth and is lower than inflation and interest rates and is estimated to be 1-3\% and 11$12 \%$ for developing countries depending on the estimation method. In Indonesia, using annual data produces an inflation threshold that is close to the estimated $n$ average of $3.62 \%$. As stated by the researchers before causality occurred between inflation to growth, but this assumption needs to be explicitly inflation can have a negative impact on economic growth [26].

The implication of this research is that real factors will not change which means that financial policy is 'neutral'. The implications of this study are very important to determine the Fisher effect in carrying out future monetary policy. Besides that it is necessary to perpetuate the inflation rate below the inflation threshold level, this situation will encourage the country's economic growth. But not only is it influenced by factors in the country but also influenced by factors outside the country such as inflation imported. Therefore, empirical results can be used as a reference to policy makers in setting inflation and optimal threshold which is nothing but related to the interest rate and economic growth.

\section{Acknowledgments}

This research was supported by the Faculty of Economics, Bung Hatta University, Padang, West Sumatra, Indonesia. 


\section{References}

[1] Tanzi, V. (1984). Taxation, inflation, and interest rates. Washington, StateDC: International Monetary Fund.

[2] Fisher, Irving. (1930). The theory of interest. New York: Macmillan

[3] Fahmy, Yasser A. F. \& Magda Kandil. (2003). The Fisher effect: new evidence and implications. International Review of Economics \& Finance. 12 (4): 451-465.

[4] Monnet, Cyril \& Warren E. Weber. (2001). Money and Interest Rates. Federal Reserve Bank Of Minneapolis, Quarterly Review.

[5] Law, Siong Hook, Hui Boon Tan \& Ahmad Zubaidi Baharumshah. (1999). Financial Liberalization in ASEAN and the Fisher Hyphothesis. Jurnal Ekonomi Indonesia. 33: 65-86.

[6] Hawtrey, K. M. (1997). The Fisher effect and Australian interest rates. Applied Financial Economics, Taylor \& Francis Journals, vol. 7(4), pages 337-346.

[7] Bank Indonesia. 2018. Inflasi. Diakses dari Bank Indonesia website: http://www.bi. go.id

[8] Johansen, Soren and Katarina Juselius. (1990). Maximum Likelihood Estimation and Inference on Cointegration- with Applications to the Demand for Money. Oxford Bulletin of Economics and Statistics 52(2): 169-210.

[9] Moazzami, B. (1991). The Fisher Equation Controversy Re-examined. Applied Financial Economics, I,pp. 129-133.

[10] Lee Coppock and Marc Poitras. (2000). Evaluating the Fisher effect in long-term cross-country averages. International Review of Economics \& Finance. 9 (2): 181-192.

[11] MacDonald, R. and Murphy, P. D. (1989). Testing for the Long Run Relationship Between Nominal Interest Rates and Inflation Using Cointegration Techniques. Applied Economics 21, 439-447.

[12] Söderlind, P. (2001). Monetary policy and the Fisher effect. Journal of Policy Modeling. 23 (5): 491-495.

[13] Adisetiawan. (2009). Hubungan tingkat suku bunga sertifikat Bank Indonesia (SBI), inflasi dan indek harga saham gabungan (IHSG). Benefit Jurnal Manajemen dan Bisnis, Vol 13(1) Juni.

[14] Banu Yodiatmaja. (2012). Hubungan antara BI rate dan Inflasi pendekatan kausalitas Toda-Yamamoto. Journal of Economics and Policy. 5(2): 117-229.

[15] Al-Khazali, Osamah. (1999). Nominal Interest Rate And Inflation In The Pacific Basin Countries. Management Decision, 37(6),491-498. 
[16] Nezhad, Mansour Zarra \& Zarea Ruhollah. (2007). Investigating The Causality Granger Relationship Between The Rates of Interest and Inflation in Iran. Journal of Social Science. 3(4), 237-244.

[17] Nasution, Nurmaito Miranda. (2009). Kausalitas Kebijakan Moneter Dengan Inflasi di Indonesia. Yogyakarta: UGM.

[18] Gul, Ekrem., \& Ekinci, Aykut. (2006). The Causal Relationship Between Nominal Interest Rates and Inflation: The Case of Turkey. Scientific Journal of Administrative Development 4: 54-69.

[19] Atkins F.J., and Serletis, A. (2003). Bounds tests of the Gibson paradox and the Fisher effect: evidence from low frequency international data. The ManchesterSchool, 71, 673-679.

[20] Rapach, D.E. (2003). International evidence on the long run impact of inflation. Journal of Money, Credit, and Banking, 35, 23-48.

[21] Shigeyoshi Miyagawa, Yoji Morita. (2003). The Fisher Effect and The Long-Run Phillips Curve. in the case of Japan, Sweden and Italy. Working Papers in Economics no 77.

[22] Mark J. Jensen. (2006). The Long-Run Fisher Effect: Can It Be Tested. Working Paper Series, Federal Reserve Bank Of Atlanta.

[23] Atkins, Frank J. \& Patrick J. Coe. (2002). An ARDL bounds test of the long-run Fisher effect in the United States and Canada. Journal of Macroeconomics. 24 (2): 255-266.

[24] Antoni, Norlin Khalid, Zulkifly Osman. (2007). Kadar bunga dan inflasi: bukti lanjut. Persidangan Kebangsaan Ekonomi Malaysia. Fakulti Ekonomi dan Perniagaan, Universiti Kebangsaan Malaysia. Proseding. ISBN 978-983-3189-09-2.

[25] Sarwono, Hartadi A. dan P. Warjiyo. (1998). Mencari Paradigma Baru Manajemen Moneter dalam Sistem Nilai Tukar Fleksibel: Suatu Pemikiran untuk Penerapannya di Indonesia. Buletin Ekonomi Moneter dan Perbankan. Vol.1(1). Juli. Bank Indonesia. Hal. 26-35.

[26] Warjiyo, P. dan D. Zulverdy. (1998). Penggunaan Suku Bunga sebagai Sasaran Operasional Kebijakan Moneter di Indonesia. Buletin Ekonomi Moneter dan Perbankan, Vol.1(1). Juli. Bank Indonesia. Hal. 36-44.

[27] Fischer, S. (1993). The Role of Macroeconomic Factors in Economic Growth, Journal of Monetary Economics, vol. 32, pp. 485-512.

[28] Khan, Mohsin S and dan Senhadji, Abdelhak S. (2001). Threshold Effects in the Relationship Between Inflation and Growth. IMF Staff Papers Vol. 48(1). 
[29] Vinayagathasan, Thanabalasingam. (2013). Inflation and Economic Growth: A Dynamic Panel Threshold Analysis for Asian Economies. Journal of Asian Economies Vol. 26, page 31-41.

[30] Nicolas, Million. (2004). Central Bank's interventions and the Fisher hypothesis: a threshold cointegration investigation. Economic Modelling. 21(6): 1051-1064.

[31] Atkins, F. J. (1989). Co-integration, Error Correction and the Fisher Effect. Applied Economics, 21:1611-20.

[32] Peláez, Rolando F. (1995). The Fisher effect: Reprise. Journal of Macroeconomics. 17 (2): $333-346$.

[33] Thornton, J. (1995). The Adjustment of Nominal Interest Rates in Mexico: A Study of the Fisher Effect. Applied Economics Letters. 3: 255-257.

[34] Koustas, Zisimos \& Apostolos Serletis. (1999). On the Fisher effect. Journal of Monetary Economics. 44 (1): 105-130.

[35] Junttila, Juha. (2001). Testing an augmented fisher hypothesis for a small open economy: The case of Finland. Journal of Macroeconomics. 23 (4): 577-599.

[36] Atmadja, Adwin S. (1999). Inflasi di Indonesia: Sumber - sumber Penyebab dan Pengendaliannya. Jurnal Akuntansi dan Keuangan, 1(1), 54-57.

[37] Granger, C.W.J. (1986). Development in the study of cointegrated economic variable. Oxford Bulletin of Economics and Statistic. 48: 213-228.

[38] Pesaran, M. Hasem, Yongcheol Shin and Richard J. Smith. (2001). Bounds Testing Approaches to the Analysis of Level Relationships. Journal of Applied Econometrics 16(3): 289-326.

[39] Pesaran, M. Hasem and Bahram Pesaran. (1997). Working with Microfit 4.0: Interactive Econometric Analysis. CityOxford, Oxford University Press.

[40] Laurenceson, J and J.C.H. Chai. (2003). Financial reform and economic development in China. Edward Elgar, Cheltenham.

[41] Banergee, A., R. L. Lunsdaine, and J. H. Stock. (1992). Recursive and Sequential Tests for a Unit Root: Theory and International Evidence. Journal of Business and Economic Statistics, 10, pp. 271-278.

[42] Dickey, D.A. \& Fuller, W.A. (1979). Distribution of the estimators for autoregressive time series with a unit root, Journal of the American Statistical Association 74: 427-431.

[43] Philips, P.C.B. \& Perron, P. (1988). Testing for a unit root in time series regression, Biometrika 75: 335-346.

[44] Akaike, H. (1977). On entropy maximasitation principle. In P.R. Krishniah (eds). Application of Statistics. North-Holland, Amsterdam 
[45] Crowder, W.J. (1997). The long-run Fisher relation in Canada. Canadian Journal of Economics 30, 1124-1142.

[46] Crowder, W.J. \& D.L. Hoffman. (1996). The long-run relationship between nominal interest rates and inflation: the Fisher equation revisited. Journal of Money Credit and Banking 28, 102-118.

[47] Bardsen, Gunnar. (1989). Estimation of Long Run Coefficients in Error Correction Models. Oxford Bulletin of Economics and Statistics. 51 (2): 345-350. 